\title{
Communication Skills and Learning in Impaired Individuals
}

\author{
Murat Eliöz \\ Yasar Dogu Faculty of Sport Sciences, Ondokuz Mayis University, Turkey
}

Copyright $\bigcirc 2016$ by authors, all rights reserved. Authors agree that this article remains permanently open access under the terms of the Creative Commons Attribution License 4.0 International License

\begin{abstract}
The purpose of this study is to compare the communication skills of individuals with different disabilities with athletes and sedentary people and to examine their learning abilities which influence the development of communication. A total of 159 male subjects 31 sedentary, 30 visually impaired, 27 hearing impaired, 40 physically impaired and 31 athletes doing individual sports (wrestling and judo)- living in Samsun and aged between 18 and 22 participated in the study voluntarily. The participants signed informed consent forms and the data were collected by the researchers through interviews with the participants. Communication skills inventory which consisted of 3 sub-dimensions of mental, emotional and behavioral and the validity and reliability of which was conducted by Ersanl1 and Balc1 (1998) was used [1]. The data were analyzed with one way variance analysis (ANOVA) test. The results of the study showed that sedentary subjects had higher scores than impaired subjects and athletes in mental, emotional and behavioral sub-dimensions. In addition, it was found that hearing impaired subjects had lower scores than the scores of other groups. As a conclusion, it can be said that as a result of the negative effects of their impairment on their learning processes, impaired individuals' communication skills learning development is hindered. In addition, considering the results of the study, we believe that habits of doing individual sports are not as effective as team sports in developing communication skills. We believe that eliminating the obstacles that weaken learning skills and developing learning skills will have positive effects on communication skills.
\end{abstract}

Keywords Obstacle, Sedentary, Athlete, Communication Skill, Learning

\section{Introduction}

Effective communication skills have a facilitating effect in all kinds of human relations. Communication skills can be summarized as being sensitive to verbal and nonverbal messages, effective listening and effective reacting $[2,3]$. Communication is beyond dispute the most basic tool in meeting the needs of contemporary life. Of the communication in daily life, $9 \%$ occurs by writing, $16 \%$ occurs by reading, $30 \%$ occurs by speaking and $45 \%$ occurs by listening [4]. There are three basic elements for communication to occur, which are source, channel and destination. For the completion of the process, the message should reach the destination and a feedback should be taken from the destination [5].

For effective and successful communication, one should be aware that communication does not occur only through words. For acceptable and comprehensible message, one should use and not ignore nonverbal components of communication such as body language. Human beings need to communicate with their environment from the moment they are born, according to their social structure. While developing technology facilitates communication, the world's getting more complicated makes communication more difficult [1]. Based on this point of view, while defining communication, Cuceloglu mentions especially gestures, mimics, images, pictures and similar ways among the channels [6]. Spender and Wilson (1986) defined communication as "a process that includes two units" exchange of messages about each other" [7].

The efficacy and variety of the learning process is the basic factor on the development of all skill areas on learning. Learning is the product of the process that includes stimuli coming from the environment and the interpretation of these stimuli by central nervous system to create a response. Thus, learning becomes dependent on sensory systems, the efficiency of these functions and their functioning quality. The result of these well-functioning sensory systems and the output of this result should be assessed as product. Permanent or temporary harms on sensory systems due to a defect, impair or failure resulting from any reason can have negative effects on the learning process. This learning process causes negative results on the different skill areas of learning depending on the type of impair or the place or type of the affected organ and/or limb. According to the learning pyramid developed by Dale (1969), we remember $10 \%$ of 
what we read, $20 \%$ of what we listen to, $30 \%$ of what we see, $50 \%$ of what we listen to and see, $80 \%$ of what we listen to, see and repeat aloud, $90 \%$ of what we do (holding-touching), see, hear and repeat aloud [8]. Researches have shown that in multiple learning environments that include stimuli that target multiple senses, the learner can acquire more effective and more permanent learning [9-14]. Even if individuals have different impairments, most of the problems between them are based on communication. Individuals' having different impairments and needing special education for any reason are thought as factors that limit the communication skills of these individuals.

The habit of doing sport is known to develop motor skills performance of individuals as well as causing them to develop psychologically. Athletes' competing in front of thousands of people they do not know, being rewarded or criticized by people and the fact that they have to explain or to account in front of media takes the place of psychological training in athletes. In addition, being able to communicate well causes positive criticism and continues interaction among athletes [15]. Yıldırım and Abakay, 2015 point out that depending on gender, communication skills should be high in team sport athletes [16]. Since games in sports allow for changes in psychological and social behaviors, they are effective in acquiring skills that improve and facilitate human relations [17].

The purpose of this study is to compare the communication skills of individuals with different disabilities with athletes and sedentary people and to examine the effects of the types of disabilities on communication skills.

\section{Method}

\subsection{Participants and Study Design}

A total of 159 male subjects 31 sedentary, 30 visually impaired, 27 hearing impaired, 40 physically impaired and 31 athletes doing individual sports (wrestling and judo) actively and studying at Yaşar Doğu Faculty of Sports Sciences- aged between 18 and 22 participated voluntarily in this study which was conducted to compare the communication skills of athletes, sedentary and impaired individuals. The participants signed informed voluntary consent form.

\subsection{Measurements}

Communication Skills Inventory used in this study was first developed and used by Balc1 (1996). The number of items in the first version of the inventory, the reliability and validity studies of which were conducted, was 70 . The inventory was later applied on a sample consisting of 500 university students and as a result of the factor analysis conducted, the number of items was reduced to 45 [1].

The inventory, which was put into its final form by Ersanl1 and Balc1 (1998), consists of 45 Likert type questions. The inventory measures mental, emotional and behavioral communication skills. The responses to items are "Always", "Usually", "Sometimes", "Rarely", "Never". Always is scored as 5 , while never is scored as 1 .

There are 15 items measuring each dimension. The items belonging to each dimension are as follows:

Mental : 1,3,6,12,15,17,18,20,24,28,30,33,37,43,45

Emotional: 5,9,11,26,27,29,31,34,35,36,38,39,40,42,44

Behavioral : 2,4,7,8,10,13,14,16,19,21,22,23,25,32,41

The highest score one can get from the inventory is 225 , while the lowest score is 45 . The highest score one can get from each sub dimension is 75 , while the lowest score is 15 . In terms of dimensions, it can be said that an individual is better in the dimension from which he gets the highest score in terms of communication skills. In terms of the whole inventory, higher scores mean higher communication skill levels.

\subsection{Data Analysis}

Before analysis, normality assumption and homogeneity tests were conducted on the data. Kolmogrov- Smirnov test showed that the data were normally distributed. Since the necessary assumptions were met, one way variance analysis (ANOVA) was conducted on the data. Turkey multiple comparison test was conducted to find out which of the groups had difference when difference was found between groups.

\section{Results}

In mental sub-dimension, sedentary subjects had significantly higher scores than the visually impaired subjects $(p=0,037)$. In the emotional sub-dimension, visually impaired subjects had higher scores than the physically impaired subjects and the athletes ( $>00,0001)$. In behavioral sub-dimension, sedentary subjects had higher scores than the hearing impaired subjects $(\mathrm{p}=0,024)$. Although there was no statistical difference between other groups, it was found that being impaired caused a decrease in communication skills when compared with athletes and sedentary subjects. 
Table 1. Communication Skills Scores of the Subjects

\begin{tabular}{|c|c|c|c|c|c|c|c|c|}
\hline & & $\mathbf{n}$ & Aver. & S.D. & Min. & Max. & $\mathbf{p}$ & Difference \\
\hline \multirow{6}{*}{ Mental } & Sedentary (1) & 31 & $35,19^{\mathrm{a}}$ & 5,47 & 23,00 & 47,00 & \multirow{6}{*}{$\mathbf{0 , 0 3 7}$} & \multirow{6}{*}{$1>2$} \\
\hline & Visually imp. (2) & 30 & $31,23^{\mathrm{b}}$ & 5,49 & 21,00 & 45,00 & & \\
\hline & Hearing imp. (3) & 27 & $31,85^{\mathrm{ab}}$ & 6,64 & 21,00 & 50,00 & & \\
\hline & Physically imp.(4) & 40 & $33,93^{\mathrm{ab}}$ & 5,52 & 20,00 & 44,00 & & \\
\hline & Athletes (5) & 31 & $34,06^{\mathrm{ab}}$ & 4,93 & 22,00 & 47,00 & & \\
\hline & Total & 159 & 33,34 & 5,72 & 20,00 & 50,00 & & \\
\hline \multirow{6}{*}{ Emotional } & Sedentary (1) & 31 & $38,74^{\mathrm{a}}$ & 4,87 & 25,00 & 47,00 & \multirow{6}{*}{$<0,0001$} & \multirow{6}{*}{$1-2-4-5>3$} \\
\hline & Visually imp. (2) & 30 & $37,23^{\mathrm{a}}$ & 6,22 & 25,00 & 50,00 & & \\
\hline & Hearing imp. (3) & 27 & $31,78^{\mathrm{b}}$ & 6,26 & 23,00 & 52,00 & & \\
\hline & Physically imp. (4) & 40 & $39,15^{\mathrm{a}}$ & 5,74 & 25,00 & 52,00 & & \\
\hline & Athletes (5) & 31 & $38,65^{\mathrm{a}}$ & 4,67 & 30,00 & 51,00 & & \\
\hline & Total & 159 & 37,36 & 6,10 & 23,00 & 52,00 & & \\
\hline \multirow{6}{*}{ Behavioral } & Sedentary (1) & 31 & $37,19^{\mathrm{a}}$ & 4,91 & 29,00 & 46,00 & \multirow{6}{*}{0,024} & \multirow{6}{*}{$1>3$} \\
\hline & Visually imp. (2) & 30 & $36,57^{\mathrm{ab}}$ & 4,56 & 23,00 & 45,00 & & \\
\hline & Hearing imp. (3) & 27 & $33,26^{\mathrm{b}}$ & 6,71 & 22,00 & 56,00 & & \\
\hline & Physically imp. (4) & 40 & $34,20^{\mathrm{ab}}$ & 5,31 & 21,00 & 46,00 & & \\
\hline & Athletes (5) & 31 & $35,81^{\mathrm{ab}}$ & 5,00 & 25,00 & 46,00 & & \\
\hline & Total & 159 & 35,38 & 5,44 & 21,00 & 56,00 & & \\
\hline
\end{tabular}

\section{Discussion}

In this study, the effects of being impaired on the communication skills of impaired individuals have been researched and communication skills of individuals with different disabilities have been compared with athletes and sedentary individuals.

When the subjects' communication skills scores were analyzed, it was found that sedentary subjects had significantly higher scores than visually impaired subjects in the mental sub-dimension $(\mathrm{p}=0,037)$. In the mental sub-dimension, no statistical difference was found between the scores of visually impaired and physically impaired subjects and sedentary subjects and athletes.

The non-impaired senses of visually impaired individuals are not superior to those of individuals who can see in terms of sensitivity. The only superiority they may have is the experiences they have acquired in interpreting the stimuli they get through these senses [18]. Thus, it is understood that in the education of visually impaired individuals, importance should be places on learning with senses other than the sense of sight.

Cognitive Development/Mental Development: Visually impaired individuals are not different from people with sight in terms of cognitive competence. However, they have difficulties in using cognitive skills since people with sight can organize lots of elements and they can integrate these with visual elements. They can encode these elements in their brains easily. Since the aforementioned situation is not valid for visually impaired children, they have limitations in encoding information. They realize encoding first through touch-hearing and then smell [19].

As stated by Gencel in 2007, studies that aim practice in the learning process of the students that have this learning style and organizing educational activities that will develop their abilities to view subjects differently will be a factor that increases success [20]. We believe that the reason why visually impaired subjects in our study got lower scores than other groups in communication skills was because of the mental development and learning deficiencies caused by the visual impairment.

In emotional sub-dimension, sedentary subjects got higher scores than the visually impaired, physically impaired and the athletes $(p>0.0001)$. The development of learning abilities of hearing impaired individuals are affected more than the other impairments and thus hearing impaired individuals got the lowest scores in emotional sub-dimension. No statistically significant difference was found between the communication skills scores of the other groups in our study.

The reason why hearing impaired individuals were different from the other groups in emotional sub-dimension was thought to occur because losing their hearing ability affected their learning processes negatively and the learning inabilities that occurred caused their low levels of communication skills that could be developed by learning. In addition, since the physical inabilities of physically impaired individuals did not cause a delay in their learning processes, their values were close to those of sedentary subjects and athletes.

We believe that the reason why athletes did not higher mental sub-dimension scores than the impaired and sedentary subjects was because team sports are more effective in developing communication skills and because the subjects in the study were elite. When the literature was examined, it was found that there were studies which stated that gender is a significant factor on communication skills. In 
their study, Hergüner et al. 1977, did not find a difference between the communication skills of students of the department of Physical Training and Sport (between students who did sports and those who did not do sports) $(p>0.05)$ [21]. The communication skills levels of female students included in the study were found to be higher than those of male students $(p<0.05)$. Thus, it can be said that female university students can communicate better and more effectively than male students [21]. In studies conducted by Mutlu et al. 2014 and Çavuşoğlu and Günay, 2014, it was found that the average communication skills levels of athlete students did not show statistically significant difference in terms of the variable of gender $[22,23]$. While these results in literature support our study, there are also studies which show that gender is not a determinant or studies which show that men have higher communication skills than women.

In behavioral sub-dimension, sedentary subjects had higher scores than hearing impaired subjects $(\mathrm{p}=0.024)$. Statistically significant difference was found between the communication skills of hearing impaired subjects and sedentary subjects in behavioral sub-dimension. It is clear that the relationships of hearing impaired individuals with their environment and other people are affected more negatively than other types of impairment. Although there weren't statistical difference between the other groups, it was found that being impaired caused a decrease in communication skills when compared with athletes and sedentary subjects.

The results of the present study show that the most disadvantageous group in the development of communication skills is the hearing impaired individuals. It was found that hearing impairment affected the communication skills of people more negatively when compared with other impairment types. We think that this deficiency in communication skills is caused by learning deficiencies resulting from the impairment.

When it is taken into consideration that athletes and sedentary subjects had higher scores than the impaired individuals although there were no statistically significant differences, it can be said that being impaired affects communication skills negatively. We believe that the reason why there weren't significant differences between athletes and sedentary subjects and other impaired groups was because the athlete group in our study did not include elite athletes and because the group consisted of male athletes doing individual sports. In their study they conducted on university students, Tozoğlu et al. (2014) stated that the communication skills of students who did individual sports were higher than those who did team sports [24]. This study is not in parallel with our study. In a study conducted by Şahin (2012) on the communication skills of athletes doing team sports and athletes doing individual sports, the communication skills of athletes who did team sports were found to be higher; however, there were no significant differences [25]. This result is in parallel with the results of our study. When the studies literature in about the communication skills of athletes were examined, it was found that although there was no association between communication skills and performance, elite athletes had higher scores than other athletes in terms of communication skills; in addition, when the communication perceptions of athletes and sedentary individuals were assessed, athletes were found to have higher communication skills than sedentary individuals $[25,26]$.

To the contrary of the view in the first half of 20th century, it is known that mental skills of hearing impaired individuals are not different from those of healthy individuals. In cases where mental assessments are not verbal, or in cases where verbal directions are not given in non-verbal assessments, the performances of hearing impaired individuals are the same with hearing individuals. Hearing impaired individuals were found to pass from the early development periods of Piaget at the same time with hearing children [27]. However, in advanced ages, some differences are seen in Piaget's formal interactions period in abstract thinking and/or top level, developed thinking skills. These differences or delays can be thought to occur from their deficiencies of interaction with the language spoken around. In studies conducted with hearing impaired people in terms of semantics, difficulties were found in both recipient and transmitter vocabulary and abstract language use [28].

When academic achievements are examined, it is known that hearing impaired individuals have lower performances than their peers. This failure shows itself especially in reading and writing [29]. For example, mathematic skills are less affected than reading and writing. It was found that the difference between the achievement of hearing impaired individuals and their peers increased as years passed. Hearing impaired individuals use shorter and less complicated language while writing and they make more mistakes. Since reading and writing are language skills, these results should not be surprising. None can be expected to show reading and writing skills beyond their language skills [30].

When the reasons for the academic success of hearing impaired individuals are examined, it can be seen that the verbal intelligence of the person, earlier introduction to language and the quality of language are more important than the degree of hearing loss [31]. The academic success of hearing impaired individuals who start to learn language earlier and who develop language by getting qualified education is positively affected. These results are in parallel with the results of Çeliker and Ege's (2005) study [32].

Brunner and Majewski (1990) stated that impaired students had different learning styles [33]. Susla (1994) stated that there were variations in the learning styles of impaired students and that their learning styles could change according to the type and characteristics of their disabilities [34]. Griggs and Dunn (1984) found that learning styles varied in gifted students [35]. Gary (1994) stated that autistic students learned with methods different from each other and that their learning styles varied [36]. In their study they conducted with hearing impaired students, Lang et al. (1999) found that there were variations in the learning styles of 
hearing impaired students [37]. When studies conducted were examined, it can be seen that students generally had changing learning styles in the first row, however, different learning styles can also be seen in the first rows [38]. The integration in preschool period is very important for the impaired children to gain the basic communication skills they need to ease the adaptation of impaired children to society and to accelerate development [39].

The results of Yilmaz's (2002) study showed that more than half of the children with disabilities had difficulty of learning [40]. The prevalence rates found are very high when compared with hearing children. The learning difficulty signs of hearing impaired children focus more on the areas of comprehension and attention. It is more common in male students to show learning difficulty.

As a conclusion, it can be seen that being impaired negatively affects communication skills of individuals and among different types of impairment, hearing impaired individuals are the most disadvantageous group in terms of communication skills. However, we believe that individual sports or team sports and gender are important factors in the development of communication skills. In the light of this information, we believe that removing the deficiencies of impaired students by taking their different learning skills into consideration can cause communication skills scores to increase.

\section{REFERENCES}

[1] K. Ersanl1, S. Balc1. Developing a Communication Skills Inventory:Its Vadility and Reliability, Türk Psikoloji Danışma ve Rehberlik Dergisi Vol. 2, No. 10, 1998.

[2] S.B. Baker, M.C. Shaw. Improving counseling through primary prevention, Merrill Publishing Company. Ohio, 1987.

[3] G. Egan. Psikolojik danışmaya giriş. F. Akkoyun (Çev). Form Ofset, Ankara, 1994.

[4] R. Worth. Communication Skills, J. G. Ferguson Publishing Company, 2nd Edition, 3, NY, 2004.

[5] Ö. Demirel, S. Sefereoğlu, E. Yağc1. Öğretim teknolojileri ve materyal geliştirme, Pagem Yayıncılık, Ankara, 2001.

[6] D. Cüceloğlu, Yeniden insan insana, Remzi Kitabevi, İstanbul, 1999.

[7] D. Sperder, D. Wilson. Relevance: communication and cognition, Harvard university press, Massachusetts, 265, 1986.

[8] E. Dale. Audiovisual methods in teaching, Dryden Press. NY, 1969.

[9] J.M. Mene, J.W. Mene. The relative efficiency of bimodal presentation as an aid to learning. Audio Visual Communication Review, No. 20, 170-180, 1972.

[10] Y. Baek, B. Layne, Color, graphics and animation in a computer assisted learning tutorial lesson, Journal of Computer Based Instruction, 15, 131-135, 1988.

[11] P.M. Raupers, Effects of accommodating learning- style preferences on long-term retention of technology training content, National Forum of Special Education Journal, 9E, 2000 .

[12] E. Shepherdson, 2001.Teaching concepts utilizing active learning computer environments. Retrieved November 20, 2004 from

http://moment.mit.edu/thesisemma/pdf\%20files/thesis.htm

[13] M.E. Sezgin. İkili kodlama kuramına dayalı olarak hazırlanan multimedia ders yazılımının fen bilgisi öğretimindeki akademik başarıya, öğrenme düzeyine ve kalıcıllı̆a etkisi, Çukurova Üniversitesi, Yayımlanmamış Yüksek Lisans Tezi. Adana, 2002

[14] W. Tsoua, W. Wang, Y. Tzeng. Applying a multimedia storytelling website in foreign language learning [Electronic Version]. Computers and Education. 2004

[15] H. Ulukan. İletişim becerilerinin takım ve bireysel sporculara etkisi. Karamanoğlu MehmetBey Üniversitesi, Sosyal Bilimler Enstitüsü, Yüksek Lisans Tezi, Karaman. 2012.

[16] A. Yıldırım. U. Abakay. Investigation of The Relationship Between Hockey Players' Communication Skills and Aggression Levels. İnönü Üniversitesi Beden Eğitimi ve Spor Bilimleri Dergisi, Vol.2, No.1, 17-28, 2015.

[17] H. Çamlıyer. Eğitim bütünlüğü içerisinde çocuk hareket eğitimi ve oyun, Emek Matbaacılık, Manisa, 2001.

[18] M. Enc, D. Çağlar, Y. Özsoy. Özel eğitime giriş. Sevinç Matbaas1. Ankara. s51, 1981.

[19] E. Gencel. Learning styles, instruction based on Kolb's experiential learning theory, attitude and social studies achievement. Unpublished doctoral dissertation, Dokuz Eylül Üniversitesi, Eğitim Bilimleri Enstitüsü, İzmir, s48, 2006.

[20] D. Tazegul, U. Şen. A study on learning sytles of visually impaired students in accordance with certain variables, The Journal of International Social Research, Vol. 2, No. 8, 2009.

[21] G. Hergüner, Ö. Güven, M. Yaman. The Effect Of Sports On The Communication Skill Level Of The University Students, Pamukkale Üniversitesi Eğitim Fakültesi Dergisi, No. 3, 95-101, 1997.

[22] T.O. Mutlu, H.E. Şentürk, E. Zorba. Empathic Tendency of University Students in Tennis and Communication Skills, International Journal of Science, Culture and Sport, Vol. 1, 129-137, 2014.

[23] S.B. Çavuşoğlu, G. Günay. Perceptıons Of Communıcatıon Skills Of Students Of School Of Physical Education And Sports Of Istanbul University, Organizasyon ve Yönetim Bilimleri Dergisi, Vol. 6, No.1, 107-121, 2014.

[24] E. Tozoglu, G. Bayraktar. Effects of sports on communication skills: a research on teacher candidates. Research on Humanities and Social Sciences, Vol.4, No.2, 68-74, 2014.

[25] N. Şahin. The Comparison of Communication Sk1lls Of Two Elite Groups Performing Team And Individual Sport, Spormetre Beden Eğitimi ve Spor Bilimleri Dergisi, No.1, 13-16, 2012.

[26] Ö. Tepeköylü, M. Soytürk, H. Çamlıyer. Evaluatıon Of 
Communication Skills And Self Esteem Of The Students Who Studied At The School Of Physical Education And Sports, Spormetre Beden Eğitimi ve Spor Bilimleri Dergisi, Vol.7, No.3, 115-124, 2009.

[27] H. Furth, J. Youniss. Formal operations and language. A comparison of deaf and hearing adolescents, International Journal of Psychology, Vol. 6, 49-64. 1971.

[28] S. Easterbrooks. Speech/language intervention with school-aged gearing impaired children. In J. Alpiner ve P. McCarthy (eds). Rehabilitative Audiology: Children and Adults. Baltimore: Williams and Wilkins. 1987.

[29] C. Yoshinago Itano. Beyond the sentence level: What is in a hearing impaired child's story? Topics in Language Disorders, 6, 71-83, 1986.

[30] P. Ege. Farklı engel gruplarının iletișim özellikleri ve öğretmenlere öneriler, Ankara Üniversitesi Eğitim Bilimleri Fakültesi Özel Eğitim Dergisi, Vol. 7, No. 2, 1-23, 2006.

[31] J. Davis, J. Elfenbein, R. Schum, R. Bentler. Effects on mild and moderate hearing impairments on language, educational and psychosocial behavior of children, Journal of Speech and Hearing Disorders, Vol. 51, 53-62, 1986.

[32] Z.P. Çeliker, P. Ege. İşitme engellilerin konuşmalarının anlaş1labilirliğine etki eden faktörler, III. Ulusal Dil ve Konuşma Bozuklukları Kongresi bildirisi, Ankara, 2005.

[33] C.E. Brunner, W.S. Majewski. Mildly handicapped students can succeed with learning styles, Educational leadership. Vol. 48, No. 2, 21-23, 1990.

[34] B.M. Susla. A social emotional/awareness program for learning disabled students. Education Research İnformation Center, 1994

[35] S.A. Griggs, R.S. Dunn, Selected case studies of the learning style preferences of gifted students, Gifted Child Quarterly. Vol. 28, 115-119. 1984.

[36] B.M. Garry. Learning styles of children with autism by gary mesibov: Autism Society of America, University of North Carolina at Chapel Hill. 1994.

[37] H.G. Lang, M.S. Stinson, F. Kavanagh, Y. Liu, M.L. Basile. Learning styles of deaf college students and instructors, teaching emphases, Journal of Deaf Studies and Deaf Education. Vol. 4, No.1, 16-27. 1999.

[38] C. Aslan. A Study on the Determination of the Learning Styles of Hearing Impaired Students, Turkish Journal of Education Vol. 2, No. 2, 11-12, 2013.

[39] N. Metin. Okul öncesi dönemde özürlü çocuklar için kaynaştırma programları, Özel Eğitim Dergisi, Vol.1, No.2, 32-36, 1992.

[40] A. Y1lmaz. İșitme engelli öğrencilerin öğrenme güçlüğü belirtileri gösterme durumlarının belirlenmesi, Anadolu Üniversitesi, Eğitim Bilimleri Enstitüsü, Yüksek Lisans Tezi, 2002. 